\title{
Referentni intervali u laboratorijskoj medicini
}

1 Valentina Kolić

2 Lana Feher Turković

3 Dragana Šegulja

3 Danica Matišić

1 Alumni klub Zdravstvenog veleučilišta Zagreb

2 Zdravstveno veleučilište Zagreb

3 Klinički zavod za laboratorijsku dijagnostiku Medicinskog fakulteta Sveučilišta u Zagrebu, Klinički bolnički centar Zagreb

\section{SAŽETAK}

Laboratorijski nalazi imaju široku primjenu u medicini, od postavljanja dijagnoze bolesti, praćenja tijeka bolesti do praćenja uspješnosti terapije. Za racionalnu interpretaciju laboratorijskih nalaza potrebno je poznavanje referentnih intervala. Referentni interval obuhvaća vrijednost između gornje i donje referentne granice, uključujući i vrijednost samih granica. Najčešće je upotrebljavani i preporučeni oblik referentnog intervala 95-postotni interval koji obuhvaća $95 \%$ središnjih vrijednosti omeđenih 2,5. i 97,5. percentilom. Za izradu referentnih vrijednosti treba odabrati: referentne osobe koje čine referentnu populaciju, referentni uzorak u kojem se određuju referentne vrijednosti koje pokazuju referentnu distribuciju iz koje se zatim izračunavaju donje i gornje referentne granice koje omeđuju referentne intervale. Određivanje referentnih vrijednosti i intervala treba provesti na velikom broju zdravih ispitanika, što

Ključne riječi: referentna vrijednost, referentni interval, referentne osobe

Datum primitka: 30.03.2016.

Datum prihvaćanja: 01.05.2017.

DOI: $10.24141 / 3 / 1 / 12$

Adresa za dopisivanje:

Valentina Kolić

Tina Ujevića 28, 44000 Sisak

E-pošta: valentina.kolic6@gmail.com

Tel.: +385981887204 


\section{UVOD}

Sastojci biološkog materijala ljudi ne mijenjaju se samo zbog različitih bolesti nego i zbog fizioloških procesa, genetike, uvjeta života i životnih navika. Zato je za racionalnu interpretaciju laboratorijskih rezultata potrebno poznavanje onih vrijednosti koje po svim navedenim dodanim uzrocima razlike odgovaraju osobi čiji se rezultati evaluiraju. To su referentne vrijednosti. Rezultati mjerenja određenih analita uspoređuju se s „normalnim" vrijednostima preuzetima iz literature. ${ }^{1}$

Da bi se izbjegli nesporazumi oko često upotrebljavanog pojma „normalne vrijednosti”, 1972. godine preporučeno je da se taj pojam zamijeni pojmom ,referentna vrijednost” i „referentni interval”. Referentne vrijednosti određuju se prema rezultatima jedne što je moguće bolje definirane zdrave skupine odnosno skupine osoba bez simptoma bolesti. Tako se izgubio mnogoznačni izraz „normalno” i uveo pojam „referentno”, što zapravo znači „odgovarajuće”. ${ }^{1}$ Koncepciju naziva „referenthe vrijednosti" prvi je put prikazao R. Dybkaer u Kopenhagenu 1972. godine na 8. međunarodnom kongresu kliničkih kemičara. ${ }^{1}$

Proaktivno se problematikom definiranja, uspostavljanja i verifikacije referentnih materijala bavi dokument koji je izradila ekspertna skupina Međunarodne federacije za kliničku kemiju (engl. The International Federation of Clinical Chemistry - IFCC) EP28-A3C (ranije C28-A3C), ${ }^{2}$ koji sadrži smjernice za određivanje referentnih vrijednosti i referentnih intervala za kvantitativne kliničke laboratorijske testove, budući da koncept izrade referentnih vrijednosti podliježe promjenama. Preporuke su objavljene $u$ šest dokumenata objedinjenih u dokumentu Instituta za kliničko laboratorijske standarde (engl. The Clinical \& Laboratory Standards Institute - CLSI) C28-P3. Američka Agencija za hranu i lijekove (engl. The Food and Drug Administration - FDA) procijenila je i prepoznala ove smjernice za primjenu u zadovoljavanju regulatornih zahtjeva. Dokument pruža protokol za određivanje referentnih intervala koji udovoljavaju minimalnim zahtjevima pouzdanosti i korisnosti. Smjernice su usredotočene na referentne vrijednosti povezane sa zdravljem, budući da se odnose na kvantitativne kliničke laboratorijske testove. Uključeni su različiti zahtjevi za studije pri određivanju referentnih vrijednosti za novi analit ili novu analitičku metodu prethodno izmjerenog analita. ${ }^{2}$
U Republici Hrvatskoj izvještavanje o rezultatima laboratorijskih nalaza standardizirano je prema dokumentu Hrvatske komore medicinskih biokemičara Harmonizacija laboratorijskih nalaza u području opće medicinske biokemije iz 2004. godine. Program harmonizacije potaknut je u cilju racionalne primjene i pravilne transverzalne procjene rezultata laboratorijskih pretraga od rođenja do odrasle dobi. ${ }^{4}$ Odlukom Izvršnog odbora Hrvatske komore medicinskih biokemičara primjena preporučenih metoda i referentnih intervala obvezna je za sve medicinsko-biokemijske laboratorije RH od 1. siječnja 2005. ${ }^{4}$ Za određene pretrage koje nisu obuhvaćene navedenim dokumentom laboratorij obično preuzima referentne intervale koje navodi proizvođač reagensa, uz verifikaciju na osobama koje vjerno predstavljaju populaciju koju obuhvaća laboratorij.

Referentni interval obuhvaća vrijednosti između donje i gornje referentne granice, uključujući i vrijednosti samih granica. ${ }^{5}$ Izrada referentnih vrijednosti započinje: odabirom referentnih osoba koje čine referentnu populaciju, iz koje se odabire referentni uzorak na kojem se određuju referentne vrijednosti koje pokazuju referentnu distribuciju, iz koje se zatim izračunavaju donje i gornje referentne granice koje omeđuju referentne intervale.

Referentna vrijednost jest vrijednost dobivena mjerenjem koncentracije nekog analita u biološkom materijalu (krv, serum, plazma, likvor itd.) referentne osobe koja odgovara referentnom uzorku. Referentna osoba jest osoba definiranog statusa zdravlja izabrana za uspoređivanje po određenim kriterijima, u čijem se biološkom materijalu određuju referentne vrijednosti, a referentnu populaciju čini skup svih referentnih osoba koje zadovoljavaju definirani status.

Referentni se uzorak sastoji od odgovarajućeg broja referentnih osoba koje predstavljaju referentnu populaciju. Raspodjela referentnih vrijednosti iz kojih određujemo referentne granice naziva se referentna raspodjela. Konačni je cilj odrediti referentni interval za sve analite koji se određuju u biološkom materijalu. ${ }^{5}$

Rezultati laboratorijskih pretraga imaju široku primjenu u donošenju medicinske odluke (postavljanje dijagnoze, procjena rizika i prognoze te praćenja učinka liječenja i tijeka bolesti) pa sve do probira zdrave populacije u svrhu prevencije određenih bolesti. ${ }^{5,6}$ 


\section{IZRADA REFERENTNOG INTERVALA}

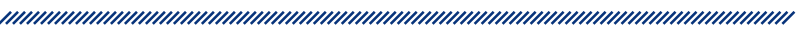

Izrada referentnog intervala za novi analit ili analitičku metodu podrazumijeva niz postupaka koji uključuju:

- pretraživanje literature u svrhu otkrivanja interferencija i izvora biološke varijabilnosti

- definiranje i sastavljanje upitnika koji sadrži kriterije prema kojima će ispitanici biti uključeni u skupinu referentnih osoba te kriterije podjele u zasebne referentne intervale, npr. prema spolu

- izradu upitnika informiranog pristanka za uključivanje u skupinu referentnih osoba

- razvrstavanje referentnih osoba prema ispunjenom upitniku

- isključivanje ispitanika koji ne zadovoljavaju uvjete prema ispunjenom upitniku

- određivanje broja referentnih osoba koje će biti uključene u studiju

- uzorkovanje i postupanje s uzorcima u skladu s rutinskim radom

- analiza raspodjele referentnih vrijednosti

- identificiranje mogućih pogrešaka i ekstremnih vrijednosti prije i poslije izračuna referentnog intervala

- odabir metoda za izračun referentnog intervala i njegovih granica

- ako je potrebno, razdvajanje referentnog intervala u podskupine

- dokumentiranje svih provedenih postupaka. ${ }^{5}$

\section{ODABIR REFERENTNE OSOBE}

Referentnom se osobom može smatrati ona osoba određene životne dobi kod koje se anamnezom i fizikalnim pregledom te uvidom u postojeću medicinsku dokumentaciju ne može utvrditi bolesno stanje koje bi utjecalo na promjenu rezultata laboratorijskih pretraga za koje se određuju referentne vrijednosti. ${ }^{1}$
Kriteriji za odabir referentne osobe:

- osobna i obiteljska anamneza

- liječnički pregled

- uvid u razne biološke čimbenike kao što su farmakološki aktivne tvari, promijenjena fiziološka stanja poput trudnoće, prisutnost rizičnih čimbenika kao što su hipertenzija, pušenje, prekomjerna tjelesna težina

- procjena rasta i razvoja kod djece

- ocjena zdravstvenog statusa

- pisani pristanak. $^{6}$

Referentna osoba definirana je vanjskim obilježjima koja su obuhvaćena u obrascu koji je ispunio liječnik istraživač tijekom pregleda i utvrđivanja stupnja zdravlja referentne osobe. Taj obrazac, osim identifikacijskog broja istraživača i referentne osobe, mora sadržavati niz podataka o referentnoj osobi na osnovi kojih se mogu isključiti bolesti, poremećaji fiziološkog stanja, rizični faktori i ovisnosti te u zaključku utvrditi da osoba, na osnovi pregleda i uvida u zdravstvenu dokumentaciju, može biti prihvaćena kao referentna.

Glavni kriteriji za isključivanje osoba iz skupine referentnih osoba:

- osobe koje se na osnovi pregleda podataka u obrascu ne mogu smatrati zdravima

- osobe koje redovito konzumiraju farmakološki aktivne tvari - lijekove radi liječenja aktivne bolesti

- promijenjena fiziološka stanja poput:

- trudnoće

- fizioloških i mentalnih stanja koje mogu izazvati stresne situacije

- konzumiranja hrane ili pića u vremenu kraćem od 10 sati prije uzimanja krvi. ${ }^{1}$

Odabir referentne osobe iz referentne populacije može se provesti na dva načina: izravno i neizravno.

Izravnim pristupom unaprijed određujemo kriterije isključivanja poput prekomjerne tjelesne težine, uzimanja lijekova, hipertenzije, genetskih čimbenika, trudnoće, stresa itd. i kriterije podjele referentnih osoba u podskupine kao što su spol, dob, faza menstruacijskog ciklusa i slično. Postavljeni kriteriji mogu imati primjenu prije uzorkovanja i analize uzoraka, a priori, ili postojeće podatke obrađujemo nakon analize, a posteriori.

Neizravno, odabir referentne osobe možemo provesti koristeći se postojećom laboratorijskom bazom poda- 
taka npr. darivatelja krvi, sistematskih pregleda itd. u kojoj se matematičkim modelom za izračun vrijednosti uzimaju rezultati koji su naizgled normalni. Ta metoda nije preporučena te se smije primijeniti isključivo u situacijama u kojima je uzorkovanje otežano i kada je teško doći do referentnog uzorka izravnim pristupom, kao što je kod pedijatrijskih uzoraka. ${ }^{5}$

Konačna odluka o tome je li osoba referentna ili nije donosi se prema nađenim laboratorijskim rezultatima. Tako se iz skupine uzoraka odabrane referentne populacije ne može prihvatiti nijedna osoba kod koje se nađu dva ili više rezultata izvan granica dotadašnjih „normalnih vrijednosti”.

\section{UKUPNA VARIJACIJA REFERENTNIH INTERVALA}

Ukupna varijacija referentnih intervala je zbir biološke varijacije, predanalitičke i analitičke varijacije. ${ }^{6}$ Rezultati laboratorijskih analiza dobivenih iz referentne populacije moraju obuhvatiti sve predanalitičke i analitičke varijacije koje bi mogle utjecati na ishod testa. Predanalitička faza laboratorijskog procesa mora imati jasno definirane postupke pripreme ispitanika, načina uzorkovanja, pohrane i obrade uzorka te potencijalne biološke varijacije. ${ }^{5}$

Danas, upravo iz razloga kako bi se izbjegle moguće varijacije, standardizirani su neki od predanalitičkih uvjeta:

- krv se vadi ujutro, 12 sati nakon zadnjeg obroka

- potrebno je da ispitanik miruje 15 do 30 minuta prije uzorkovanja

- položaj tijela za vrijeme vađenja krvi je sjedeći

- krv se uzima iz antekubitalne vene, nakon minimalne kompresije u trajanju manje od 1 minute

- uzorkovanje se izvodi u standardizirane epruvete

- sve su analize za određivanje referentnih vrijednosti obavljene istog dana kad i uzimanje krvi. ${ }^{1}$

Analitička faza mora uključivati detaljan opis metode $s$ njezinim karakteristikama:

- netočnost

- nepreciznost

- utjecaj interferencija
- linearnost

- test iskorištenja

- mjernu sljedivost

- kao i opis ostalih čimbenika koji su sastavni dio analitičkog procesa kao što su reagensi, standardi, oprema. ${ }^{5}$

Kao i kod predanalitičkih varijacija, standardizacijom analitičkih metoda pokušavaju se smanjiti analitičke varijacije koje se postižu primjenom preporučenih analitičkih metoda. Izbor metoda provodi se prema preporukama Komiteta za referentne vrijednosti IFCC-a. Posebno je važan segment u standardizaciji analitičkih metoda provođenje unutarnje i vanjske kontrole kvalitete rada. ${ }^{6}$

Intralaboratorijska kontrola kvalitete rada obuhvaća kontrolu nepreciznosti odnosno slučajne pogreške i kontrolu netočnosti tj. sistematske pogreške analitičkih postupaka koji uvjetuju raspršenost i lokaciju referentnog intervala. Interlaboratorijska kontrola kvalitete potrebna je i radi međusobnog usklađivanja rezultata pretraga i utvrđivanja eventualnog stalnog odstupanja (engl. bias - odstupanje) od „prave vrijednosti” pojedinih rezultata neke pretrage izrađene $u$ onim laboratorijima koji sudjeluju u kontroli. ${ }^{1}$

Važnost utjecaja interferencije prikazana je na tumorskom biljegu CA 19-9. Tumorski biljezi korisni su u praćenju tijeka bolesti onkoloških bolesnika zbog postojana korelacije između koncentracije tumorskoga biljega i aktivne tumorske mase. Glavni je problem tumorskih biljega što nisu organski specifični pa time nisu idealni (ne izlučuju se samo iz tumorskog tkiva i nisu specifični samo za određenu vrstu tumora i organa te se ne izlučuju u dovoljnoj koncentraciji u početnoj fazi rasta tumora). Klinička opravdanost određivanja tumorskih biljega zasniva se na sljedećem: to su neinvazivne pretrage za koje je potreban samo uzorak krvi, a kojima se omogućuju postupci dijagnosticiranja, prognoziranja, stupnjevanja i praćenja onkološkog bolesnika. Prema propisima međunarodnog udruženja ISOBM (engl. International Research Group for Carcinoembryonic Proteins) postavljeni su određeni kriteriji promjene koncentracije tumorskih biljega i odgovora na terapiju. Ako se koncentracija tumorskog biljega poveća za $25 \%$, smatra se da je riječ o progresiji bolesti, a ako se vrijednost biljega smanji za $50 \%$, riječ je o djelomičnoj remisiji ili o potpunoj remisiji ako tumorski biljeg postane nemjerljiv. Određuju se histološkim, citološkim i imunokemijskim metodama kao što su luminometrijske (engl. luminometric assay, LIA), enzimske (engl. 


\begin{tabular}{|c|c|}
\hline TUMORSKI BILJEG & Moguće interferencije i drugi analitički izvori varijacija te mogući utjecaji na rezultate \\
\hline $\begin{array}{l}\text { UGLJIKOHIDRATNI ANTIGEN 19-9 } \\
\text { (CA 19-9) }\end{array}$ & $\begin{array}{l}\text { 1. HAMA i heterofilna antitijela koja se primjenjuju u terapiji kod tumora mogu interfe- } \\
\text { rirati u imunokemijskom određivanju - povišeni ili sniženi rezultati } \\
\text { 2. pacijenti s krvnom grupom Levis (a), Levis (b) negativna zbog nedostatka enzima } \\
\text { sialil-transferaze potrebnog za sintezu Ca 19-9 epitop ( } 3 \text { do } 5 \text { \% populacije) - sniženi } \\
\text { rezultati } \\
\text { 3. menstruacija i trudnoća - povišeni rezultati } \\
\text { 4. zagađenje uzorka sekretima, osobito slinom - povišeni rezultati } \\
\text { 5. nemaligne bolesti (pankreatitis, hepatitis, ciroza jetre, druge gastrointestinalne bo- } \\
\text { lesti, cistična fibroza) - povišeni rezultati }\end{array}$ \\
\hline
\end{tabular}

enzyme assay, EIA) i fluorometrijske (engl. fluorometric assay, FIA), a samo iznimno radioimunološkim (engl. radioimmunoassay, RIA) i imunoradiometrijskim (engl. immunoradiometric assay, IRMA) metodama. ${ }^{7}$

Primjer mogućih interferencija koje mogu dovesti do lažno pozitivnih ili lažno negativnih vrijednosti tumorskog biljega CA 19-9 prikazane su u tablici $1 .^{8}$

\section{STATISTIČKA OBRADA REZULTATA}

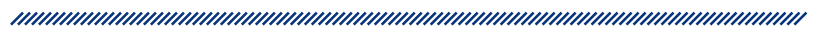

Preporučeni je oblik referentnog intervala, koji se najčešće i upotrebljava, 95-postotni interval koji obuhvaća 95\% središnjih vrijednosti omeđenih 2,5. i 97,5. percentilom. Percentili označavaju granične vrijednosti prema kojima su ostale izmjerene vrijednosti $2,5 \%$ odnosno $97,5 \%$ manje od graničnih vrijednosti ili su im jednake. U nekim je slučajevima važna samo gornja vrijednost odnosno 97,5. percentil. ${ }^{5}$ Jedan je od primjera u kojima je važna samo gornja granica CA 19-9, tumorski antigen koji se upotrebljava kao biljeg karcinoma gušterače i bilijarnog trakta, za koji referentni interval ( $\mathrm{m}, \mathrm{z}$ - odrasli) iznosi: < 37,0 kIU/L. ${ }^{9}$ Povećane koncentracije antigena CA 19-9 u serumu opažene su ponekad i u bolesnika s pankreatitisom i drugim dobroćudnim bolestima gastrointestinalnog trakta.

Nakon analize uzoraka dobivene rezultate prikazujemo histogramom tako da se na ordinatu nanosi učestalost, a na apscisu izmjerene vrijednosti. Vizualnim se pregledom raspodjele podataka mogu prepoznati ekstremne vrijednosti koje mogu biti izvor pogrešaka u mjerenju. Nakon vizualnog pregleda ispitujemo normalnost raspodjele podataka primjenom raznih statističkih testova te, ako smatramo da interval treba razdvojiti u podskupine, ispitujemo normalnost raspodjele za svaku podskupinu. Nakon što smo to ispitali, slijedi izračun referentnog intervala za koji je važan pravilan odabir metode koja se temelji na broju uzoraka $(\mathrm{N})$ i raspodjeli podataka.

Statistički su modeli za izračunavanje referentnog intervala:

- parametrijska metoda

- neparametrijska metoda

- metoda grube procjene te

- metoda ponovljenog uzorkovanja.

Neparametrijska metoda preporučena je metoda prema smjernicama Instituta za kliničke i laboratorijske standarde (engl. Clinical and Laboratory Standards institute - CLSI) za izračun referentnih intervala. Preporučeni je broj uzoraka 120, a metoda ne uzima u obzir tip raspodjele podataka, već svakoj izmjerenoj vrijednosti dodjeljuje rang, tj. redoslijed u nizu vrijednosti poredanih po veličini. Metoda se temelji na odbacivanju određenog postotka referentnih vrijednosti, najčešće $2,5 \%$, koje se nalaze na svakom kraju raspodjele podataka.

Parametrijsku metodu možemo primjenjivati samo ako referentne vrijednosti slijede Gaussovu raspodjelu podataka. Gaussova krivulja grafički je prikaz rezultata i u potpunosti je definirana aritmetičkom sredinom, koja određuje središte, i standardnom devijacijom, koja određuje širinu. ${ }^{5}$ Najmanji je broj uzoraka 120 . Prilikom procjene o normalnoj raspodjeli podataka moramo obvezno uzeti u obzir i parametre koji opisuju spljoštenost $\mathrm{i}$ iskošenost krivulje, s obzirom na to da ponekad raspo- 
djela podataka može naizgled imati Gaussov oblik, no ti parametri mogu blago odstupati i pridonijeti pogrešnom određivanju referentnih granica.

Metodu grube procjene primjenjujemo kada je broj uzoraka manji od 120, a podatci ne moraju slijediti Gaussovu raspodjelu.

Metoda ponovljenog uzorkovanja koristi se matematičkim modelom u kojem se iz cijelog skupa podataka nasumice odabire određeni broj izmjerenih vrijednosti. $Z a$ izračun je potrebno najmanje 100 izmjerenih vrijednosti. Kao i metoda grube procjene, ne uzima u obzir tip raspodjele podataka. Možemo je odabrati ako primjena parametrijske ili neparametrijske metode nije moguća s obzirom na kriterij veličine uzorka.

Osim statističkih metoda, programi nude mogućnost izračuna intervala pouzdanosti za referentne granice pripadajućih referentnih intervala. Intervali pouzdanosti predstavljaju raspon vrijednosti unutar kojih s određenom vjerojatnošću možemo očekivati vrijednosti unutar referentnih intervala te što je taj interval pouzdanosti uži, s većom smo preciznošću odredili referentnu granicu. $\mathrm{Naj}$ češće su korišteni intervali pouzdanosti $90 \%$ i $95 \%$. Ako procijenimo da je interval pouzdanosti referentnih granica preširok, tada moramo povećati broj uzoraka kako bismo s većom preciznošću procijenili referentne granice. ${ }^{5}$

\section{VERIFIKACIJA INTERVALA}

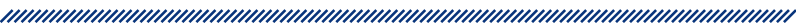

Tumačenje laboratorijskih rezultata pretraga provodi se analizom individualnog rezultata u odnosu na referentne intervale određene na referentnoj populaciji. Referentni intervali mogu znatno utjecati na korisnost laboratorijskih rezultata. Njihovu izradu za sve laboratorijske pretrage moraju osigurati kako klinički laboratoriji tako i proizvođači komercijalnih reagensa u skladu s direktivom IVD 98/79/EC.

Preporučuje se za svaku validiranu laboratorijsku pretragu učiniti ocjenu bioloških referentnih intervala neovisno o tome primjenjuju li se harmonizirani referentni intervali ili preporučeni referentni intervali iz literaturnih izvora.

Ocjenom je potrebno definirati:

- analit za koji se primjenjuju referentni intervali

- analitičku metodu
- moguće predanalitičke varijacije

- udio referentne populacije

- literaturne izvore podataka

- subpopulaciju (npr. spol)

- način izražavanja

- kliničko značenje i primjenu

- moguću primjenu ,jedinstvenih referentnih intervala" (uz potvrdu zadovoljavajućih analitičkih ciljeva kvalitete i validaciju prihvatljivosti)

- odluku o primjeni odgovarajućih referentnih intervala.

lako bi svaki laboratorij trebao napraviti referentne intervale za svoju ispitivanu populaciju, iz ekonomskih razloga najčešće se koristimo referentnim intervalima iz drugih izvora. Uporaba tih referentnih intervala dozvoljena je ako smo osigurali usporedivost analitičkog sustava i referentnog uzorka na kojem je referentni interval napravljen. Provjera takvog intervala može se provesti na tri načina:

1. subjektivnom procjenom

2. verifikacijom s manjim brojem referentnih osoba (na 20 referentnih osoba koje zadovoljavaju sve postavljene kriterije za referentnu populaciju)

3. verifikacijom na većem broju referentnih osoba (primjerice na 60 referentnih osoba). ${ }^{10}$

\section{DISKUSIJA}

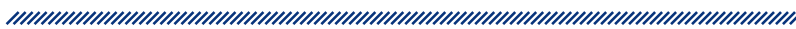

Laboratorijski nalazi imaju široku primjenu u medicini i upotrebljavaju se pri postavljanju dijagnoze bolesti, praćenju tijeka bolesti, kao i uspješnosti terapije. Cilj je rada svakog laboratorija postići pouzdanost rezultata laboratorijskih analiza, odnosno dostići analitičku pouzdanost koju definiraju točnost i preciznost analitičkog postupka. Vodeći računa o točnosti i preciznosti svakog analitičkog postupka, dobivene će vrijednosti analiza nakon obrade raznih analita biti najbliže pravoj vrijednosti sastojaka u ispitivanim uzorcima bilo kojeg biološkog materijala. Kako bi tumačenje rezultata laboratorijskih analiza bilo što točnije, u nepoznavanju prave vrijednosti sastojaka u ispitivanim uzorcima potrebno je odrediti granice pouzdanosti analitičkog rada odnosno referentne intervale. Svaki rezultat laboratorijskih pretraga mora se tumačiti individualno u odnosu 
na referentne intervale koji su prethodno određeni na referentnoj populaciji.

Da bi tumačenje nalaza bilo pouzdano, za svaku skupinu ispitanika potrebno je poznavanje referentnih vrijednosti i referentnih intervala. Kao što je navedeno, za izradu referentnih vrijednosti treba odabrati: referentne osobe koje čine referentnu populaciju, referentni uzorak u kojem se određuju referentne vrijednosti koje pokazuju referentnu distribuciju, iz koje se zatim izračunavaju donje i gornje referentne granice koje omeđuju referentne intervale.

Može se zaključiti da referentni intervali direktno utječu na dijagnostičku vrijednost laboratorijskih rezultata, stoga je potrebno u svakom laboratoriju osigurati njihovu izradu za sve laboratorijske analite. Određivanje referentnih vrijednosti i referentnih intervala opsežan je postupak i treba ga provoditi na velikom broju zdravih ispitanika, što predstavlja vrlo dugotrajan i skup proces. Tako se u laboratorijskoj praksi uglavnom upotrebljavaju referentne vrijednosti i intervali koje navodi proizvođač korištenih testova pa je potrebno izvršiti provjeru navedenih referentnih intervala.

Prema preporukama struke, svaki je laboratorij dužan verificirati referentne intervale proizvođača korištenih testova kako bi provjerio jesu li prikladni za populaciju bolesnika koju pokriva određeni laboratorij.

\section{ZAKLJUČCI}

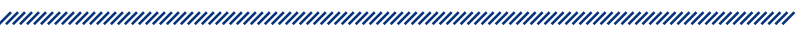

1. Referentni intervali utječu na pouzdanost tumačenja laboratorijskih rezultata pa tako i na njihovu korisnost i upotrebljivost u dijagnostici.

2. Određivanje referentnog intervala za svaki analit u bilo kojem uzorku biološkog materijala vrlo je važna faza svakog laboratorijskog rada i stoga je potrebno ili osigurati njihovu izradu za sve laboratorijske pretrage ili omogućiti provjeru prihvaćenih referentnih intervala od proizvođača korištenih reagensa.

3. Prema preporukama struke, referentne intervale dovoljno je provjeriti na 20 uzoraka zdravih ispitanika. Provjeravanje se ponavlja periodično, preporučuje se jednom godišnje ili kod promjene bilo kojih uvjeta koji mogu znatno utjecati na primjenjivani referentni interval.

\section{LITERATURA}

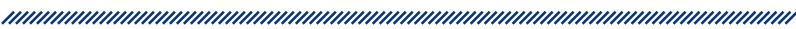

4. Šubić N, Tadej D. Referentne vrijednosti klinički relevantnih sastojaka krvi i seruma. Model: Odabiranje referentnih osoba. Zagreb: Školska knjiga; 1990: 9-30.

5. CLSI and IFCC. C28-A3 document: Defining, establishing and verifying reference intervals in the clinical laboratory: approved guideline, 3. izd. 2008; 28: 1-76.

6. Flegar-Meštrić Z. Novi pristupi izradi i primjeni bioloških referentnih intervala prema akreditacijskim zahtjevima (New approach for the production of reference intervals according to the accreditation requirements) u: Stavljenić Rukavina A. Organizacija i poslovanje medicinsko-biokemijskih laboratorija u kontekstu reforme zdravstvenog sustava. Zagreb: Medicinska naklada, 2009, 55-71.

7. Stavljenić Rukavina A, Čvorišćec D. (ur.) Harmonizacija laboratorijskih nalaza u području opće, specijalne $i$ visokodiferentne medicinske biokemije. Hrvatska komora medicinskih biokemičara, Zagreb: Medicinska naklada, 2007.

8. Zec I. Referentni intervali - izrada i verifikacija. U: Šimundić AM. Upravljanje kvalitetom laboratorijskog rada. Zagreb: Medicinska naklada, 2013: 65-78.

9. Flegar-Meštrić Z, Preden-Kereković V, Vrhovski-Hebrang D, Šurina B, Nazor A. Referentne vrijednosti biokemijskih i hematoloških sastojaka krvi i seruma zdravih osoba u dobi od 8 do 70 godina. Biochemia medica. 2000;1-2; 1-9.

10. Topić E, Primorac D, Janković S. Medicinsko-biokemijska dijagnostika u kliničkoj praksi. Zagreb: Medicinska naklada, 2004: 316-318.

11. Honović L. Kako primjenjivati tumorske biljege u kliničkoj praksi. Glas. pul. boln. 2011; 8: 19-27.

12. Čvorišćec D, Čepelak I. Štrausova medicinska biokemija. Zagreb: Medicinska naklada, 2009.

13. Flegar-Meštrić Z. Postupci ispitivanja (5.5) - kratka analitička validacija. U: Galjanić S, Vukasović I, Flegar-Meštrić Z, ur. Akreditacija medicinsko-biokemijskog laboratorija. Zagreb: HKMB, 2010. 


\section{REFERENCE INTERVALS IN LABORATORY MEDICINE}

1 Valentina Kolić

2 Lana Feher Turković

3 Dragana Šegulja

3 Danica Matišić

1 Alumni club University of Applied Health Sciences, Zagreb

2 University of Applied Health Sciences, Zagreb

3 Department of Laboratory Diagnostics, University Hospital Centre Zagreb, Zagreb

\section{ABSTRACT}

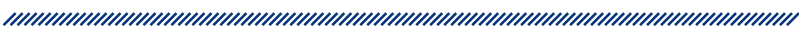

Laboratory findings are widely used in medicine; from the diagnosis monitoring the disease to tracking success of therapy. For a rational interpretation of laboratory results it is necessary to be familiar with reference intervals. Reference interval includes the value between the upper and lower reference limits, including the values of the limits. The most commonly used and recommended form of the reference interval is $95 \%$ interval which covers $95 \%$ of the central values, confining with 2.5. and 97.5. percentiles. To create the reference values should be selected: the reference persons comprising the reference population, reference samples in which is determined reference values. Reference values shows the reference distribution from which then are calculated lower and upper reference limits delimiting reference intervals. Determination of reference values and intervals must be carried out on a large number of healthy subjects which is a lengthy and expensive process. Therefore, in laboratory practice are used mainly baseline and intervals specified by the manufacturer. According to the recommendations of the profession each laboratory must verify manufacturer reference intervals to confirm that they are suitable for the intended patient population. It is possible to verify reference interval using few procedures and is important to repeat verification periodically once a year or by changing any conditions that may have a significant influence on the applied reference interval. Of the few recommended procedures most often is used the one which includes 20 healty subjects.

Keywords: reference value, reference interval, reference person 